\section{British Commonwealth Scientific Conference}

A Conference was opened by the Right Hon. Walter Elliot, M.P., Minister for Agriculture, and attended by representatives of the Governments of all portions of the British Commonwealth, on the morning of Monday, September 21, in London. Its chief function is to examine the work and future of a number of scientific organizations established on a co-operative basis to perform a common service in various branches of agricultural scientific research. As a result of the Imperial Agricultural Research Conference of 1927, the several Governments of the Empire agreed to establish bureaux or centres of information in eight branches of agricultural science, financed by contributions from all parts and controlled by a council representative of all parts of the Empire. To these, the supervision of two older institutes was added in 1933 on the recommendation of the Imperial Committee on Imperial Economic Consultation and Co-operation. In addition, the Conference is considering the future of certain research schemes to which several parts of the Empire now contribute, and also further methods of the interchange of information and closer collaboration in scientific work.

After the opening meeting on Monday, the Conference inspected the bureaux and centres of information which deal with mycology, soil science, animal health, animal nutrition and genetics, plant genetics (non-herbage and herbage), fruit production, and agricultural parasitology. The Conference re-assembles in London on October 2. The Executive Council of the Imperial Agricultural Bureaux, of which Sir Charles Howell Thomas is the chairman, is responsible to all Governments of the Empire equally for the administration of these common services, and in conformity with the resolution of the Imperial Conference of 1926 is constituted on a basis of equality of representation. It was decided by the Governments in 1933 that where such common organizations are formed, their activities should be subject to detailed examination at periodical conferences. This Conference serves that purpose.

\section{Species in Foraminifera}

THe veteran palæontologist, Frederick Chapman, who has retired from the National Museum at Melbourne and is now consulting palæontologist to the Commonwealth of Australia, has contributed to the Melbourne Age (under the initials F.C. and under date February 8, 1936) a column headed "The Species Nightmare: an Absorbing Scientific Problem". One of the oldest living authorities on the Foraminifera, trained under H. B. Brady, W. Kitchen Parker and W. Rupert Jones, whose assistant he was until his appointment to Melbourne, he deals with this difficult question, quoting Mr. Heron-Allen's communications to Nature of July 14, 1934 and November 16, 1935. Frederick Chapman deals with it in connexion with other branches of palæontology, and deplores what Heron-Allen termed "the commercialisation of Protozoology", and his article, which is worth the serious attention of all systematists, but is too long to quote adequately, should receive careful attention. Mr. Heron-Allen is consulted by many of the rising school of petroleum geologists at the Natural History Museum, and, regard being had to the deplorable fact that their lists of species are now regarded as a 'trade secret' not to be divulged for the information of rival petroleum merchants, his advice to these young men is to adhere to the genera established by the great nineteenth century school, both in England and on the Continent of Europe, and to distinguish their species, for their own reference and guidance, only by numbers, or by letters of the alphabet, ignoring the thousands of names given to minor varieties by the American School. By this means they can save themselves an immense amount of labour and brain-fag, and their tabulated results are quite as useful as they would be if they were overloaded by a vast nomenclature which it is impossible -and unnecessary--for the human brain to retain.

\section{Invention and the Modern State}

THE externals of modern civilization are the products of invention, and a scientific analysis of invention, what it is, what causes it and whither it is leading us, is long overdue in England. In such an analysis the statistical method must predominate and the easy generalization will have no place. It may require research of a difficult and unusual kind, but unless we know, for example, accurately and in detail, the origins, the training and the methods of successful present-day inventors, we do not know the sources of the real progress-making inventions of to-day, and while we are ignorant of that vital fact the recital of a short list of so-called workingman inventors of the eighteenth century is not merely valueless but also misleading. Mr. C. W. Marshall has just concluded in the Inventor a series of articles on "The Science of Invention". In them he attempts to interest and guide inventors of various degrees of proficiency, but, although the trend of recent patent applications can be learned from them, the articles are entirely devoid of statistics. As a consequence of this and of the very diverse standards of the inventors to whom the articles are addressed, their total effect is confusion. At one place advice is being given as to the "psychological factor" ; for example, "a camera idea, may be submitted to manufacturers in the autumn so as to be ready for the spring sales". Shortly after this we learn-or do we ? - that the "price of inventions used to vary from $£ 1,000$ for 'gadgets' to half a million for inventions such as refrigeration and automatic photo machines". Again, "There is a ready market for inventions which cheapen production of exclusive products. By introducing mass-production machines and an entirely re-designed, simplified product the early Fords were able to tap the potentially great motor-buying publie".

No one, it would appear, would care to challenge Mr. Marshall's contention that "so keen is the competition, so deep the technical advance now, that the 